\title{
Wpływ drgań ultradźwiękowych na kształt i strukturę przetopień wykonanych wiązką lasera w stopie aluminium
}

\author{
Effects of ultrasonic vibrations on laser beam welded \\ aluminium alloy fusion welds shape and structure
}

\section{Streszczenie}

W artykule przedstawiono wyniki badań strukturalnych nad wpływem ultradźwiękowych drgań mechanicznych o dużym natężeniu wprowadzanych poprzecznie do kierunku przetapiania laserem stopu aluminium 2017A na budowę i strukturę strefy przetopienia. Badania struktury przetopień zostały przeprowadzone za pomocą analizy fraktalnej.

Słowa kluczowe: drgania ultradźwiękowe, struktura strefy przetopienia, spawanie laserowe

\section{Abstract}

The study is concerned with the effect of highintensity ultrasonic vibrations propagated crosswise to overlaying welding direction on the structure of fusion welds produced by 2017A alloy by laser beam welding process. The structure of weld was done by fractal analysis.

Keywords: ultrasonic vibration, structure of welds, laser beam welding

\section{Wstęp}

Wykorzystanie drgań mechanicznych w celu poprawy struktury i własności połączeń sprowadza się w wielu przypadkach do bezkrytycznego stosowania drgań i obserwacji efektów. Właściwe zastosowanie drgań do modyfikacji procesów spajania stanowi wciąż wyzwanie dla technologów ze względu na niedoskonałość technicznych rozwiązań dotyczących wprowadzania drgań. Jednym z ważnych czynników które należy uwzględnić jest kierunek z którego wprowadzane są drgania w stosunku do kierunku poruszania się źródła ciepła. Jedne z pierwszych prób zbadania jaki wpływ ma kierunek wprowadzanych drgań na strukturę uzyskiwanych napoin opisano w [1,2]. Choć długość stosowanych w ramach prac eksperymentalnych fali drgań o częstotliwości $20 \mathrm{kHz}$ w stopie aluminium 201671A wynosi $0,254 \mathrm{~m}$ to wyniki badań $[1,2]$ pokazują, że nie bez znaczenia jest, z której strony drgania propagują w stosunku do poprzecznie usytuowanego ściegu. Podejmowane, nieliczne próby modyfikacji klasycznych procesów spawania poprzez zastosowanie drgań ultradźwiękowych dowodziły, że uzyskuje się różne efekty w zależności od częstotliwości drgań jak i od miejsca oraz sposobu ich wprowadzania w stosun-

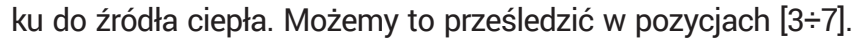
W niniejszym artykule opisano wyniki badań przeprowadzonych $w$ trakcie przetapiania laserem co pozwoliło na uniezależnienie się od zakłóceń spowodowanych niestabilnością źródła ciepła jak i dużą objętością fazy ciekłej w jeziorku spawalniczym.

\section{Metodyka badań}

W ramach pracy zostały przeprowadzone eksperymenty przetapiania wiązką lasera $\mathrm{CO}_{2}$ przy udziale drgań ultradźwiękowych oraz bez nich. Przetapianie wykonano na płaskich powierzchniach bocznych poprzecznie do osi falowodu, który był w kształcie prostopadłościanu o wymiarach $0,254 \times 0,03 \times 0,03 \mathrm{~m}$ wykonanego ze stopu aluminium 2017A (rys. 1). Długość falowodu $(0,254 \mathrm{~m})$ była równa długości ultradźwiękowych drgań stojących o częstotliwości 20 kHz.

Eksperymenty przetapiania prowadzono na stanowisku badawczym (rys. 2) składającym się z falowodu sprzężonego z przetwornikiem piezoelektrycznym o częstotliwości $20 \mathrm{kHz}$ połączonym $\mathrm{z}$ generatorem ultradźwiękowym o mocy $2,5 \mathrm{~kW}$ za pomocą koncentratora o wzmocnieniu 1/1. Do przetapiania zastosowano laser $\mathrm{CO}_{2}$ o mocy $2,5 \mathrm{~kW}$ firmy VEGMANN-BASSEL Zastosowano jedno modową wiązkę o mocy $1,5 \mathrm{~kW}$ a proces przetapiania prowadzono $w$ argonie $z$ prędkością 0,5 m/min.

Przetopienia wykonano w charakterystycznych dla przebiegu drgań miejscach odległych od początku falowodu o 0,063; 0,095; 0,127; 0,159 i 0,1905 m. Następnie wykonano przekroje poprzeczne przetopień dla poszczególnych przypadków i przeprowadzono badania mikrostruktury. W przypadku strzałki drgań występującej w odległości 0,127 m przeprowadzono dodatkowo analizę fraktalną otrzymanej struktury przetopienia.

Dr hab. inż. Arkadiusz Krajewski, mgr inż. Michał Hudycz, dr inż. Jarosław Grześ - Politechnika Warszawska, Zakład Inżynierii Spajania. 

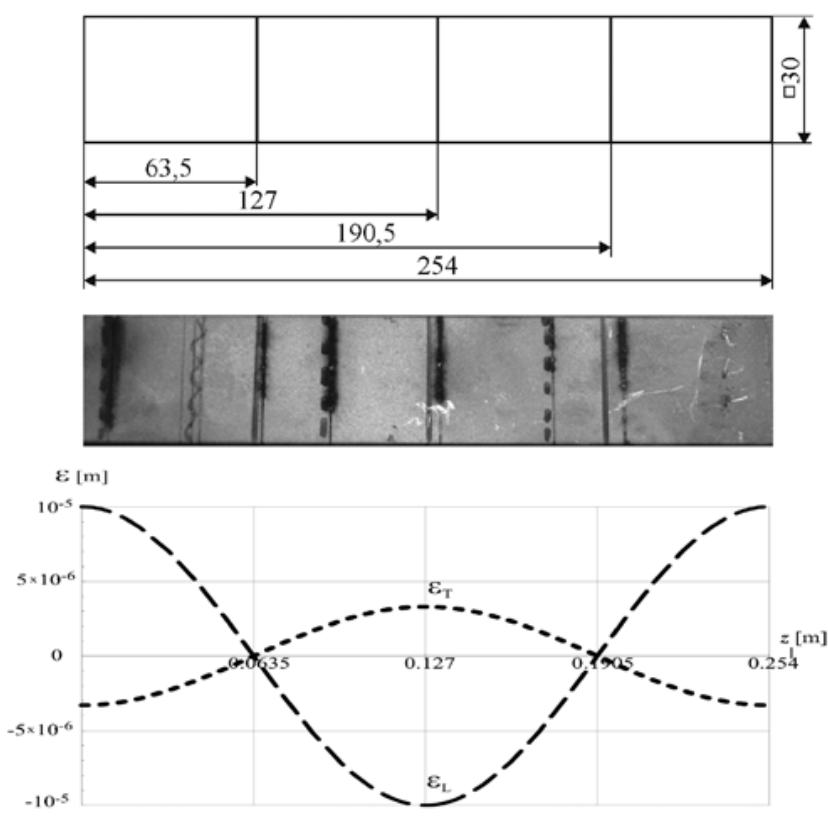

$\sigma, \sigma_{\mathrm{z}}, \tau[\mathrm{Pa}]$

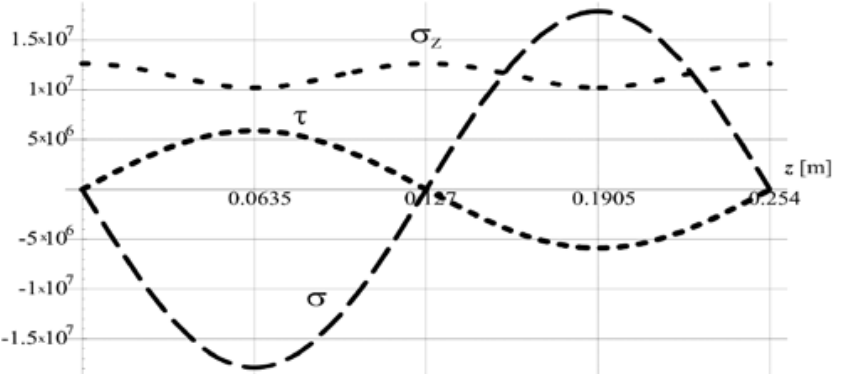

Rys. 1. Wymiary falowodu ze stopu 2017A zastosowanego w eksperymencie [mm] i widok wykonanych przetopień (pierwsza od prawej wykonana bez drgań, a kolejne $z$ drganiami) oraz przebieg przemieszczeń, podłużnych $\varepsilon_{\llcorner}$i poprzecznych $\varepsilon_{T} \mathrm{~W}$ falowodzie, rozkład naprężeń osiowych $\sigma$, poprzecznych $\mathrm{T}$ i zredukowanych $\sigma_{\mathrm{z}}$

Fig. 1. The waveguide dimensions in $\mathrm{mm}$ and padding welds view (right sight reached without vibrations, the next with vibrations) and distribution of longitudinal displacement $\varepsilon_{\llcorner}$and transversal displacement $\varepsilon_{\mathrm{T}}$, and axial stresses $\sigma$, transverse stresses $\mathrm{T}$, and reduced stresses $\sigma_{z}$

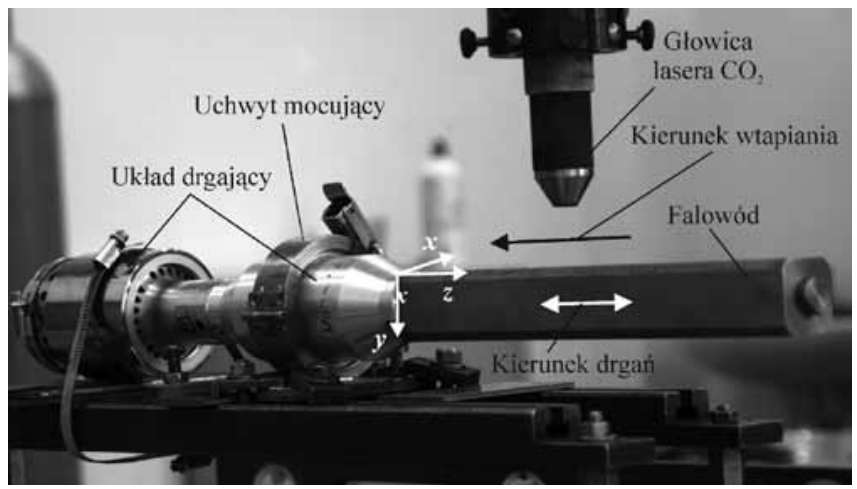

Rys. 2. Stanowisko do prób przetapiania laserem z układem drgającym Fig. 2. Experimental laser welded set-up with the vibration unit

\section{Badania metalograficzne}

Po przetapianiu odcinki z napoinami wycięto prostopadłe do osi przetopienie. Otrzymane przekroje szlifowano, polerowano i trawiono odczynnikiem Kellera. W ramach badań makrostrukturalnych wykonano serię zdjęć przedstawiających widoki i profile poprzeczne uzyskanych napoin. Przeprowadzone badania strukturalne miały charakter porównawczy, a ich wyniki przedstawiono na rysunku $3 \div 8$.

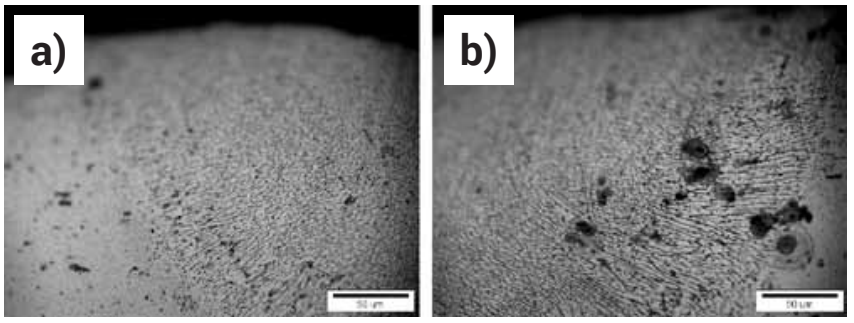

Rys. 3. Struktura wtopienia układanego metodą LW na stopie aluminium 2017A bez zastosowania drgań ultradźwiękowych. Lewa strona wtopienia a), prawa b)

Fig. 3. Structure of 2017A alloy after laser welding without ultrasonic vibration. Left side a), right side $b$ )
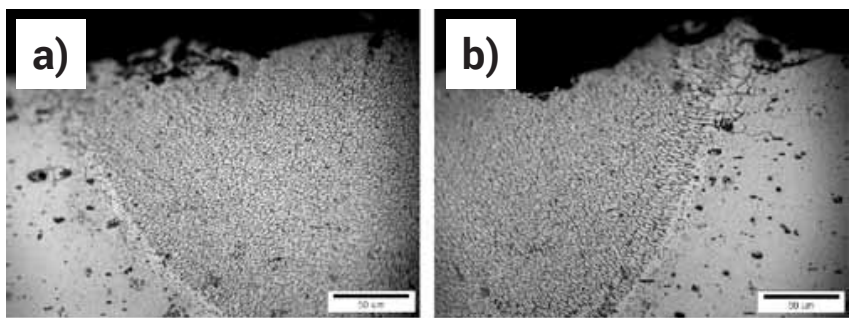

Rys. 4. Struktura wtopienia układanego metodą LW na stopie aluminium 2017A z zastosowaniem drgań ultradźwiękowych. Kierunek propagacji drgań od strony prawej przetopienia b) do strony lewej a). Przekrój poprzeczny wykonany w odległości $z=0,0635 \mathrm{~m}$ od mocowanego czoła falowodu

Fig. 4. Structure of $2017 \mathrm{~A}$ alloy after laser welding with ultrasonic vibration. Cross section at the distance $z=0,0635 \mathrm{~m}$ from the fixed waveguide face. Propagation direction is from right side b) to left side a)
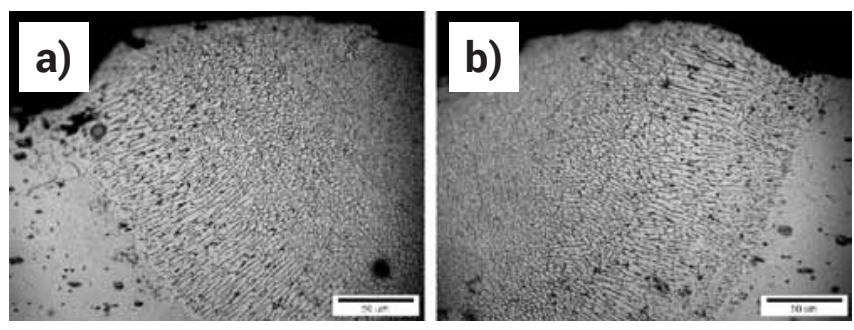

Rys. 5. Struktura wtopienia układanego metodą LW na stopie aluminium 2017A z zastosowaniem drgań ultradźwiękowych. Kierunek propagacji drgań od strony prawej napoiny b) do strony lewej a). Przekrój poprzeczny wykonany w odległości z $=0,090 \mathrm{~m}$ od mocowanego czoła falowodu

Fig. 5. Structure of 2017A alloy after laser welding with ultrasonic vibration. Cross section at the distance $z=0,090 \mathrm{~m}$ from the fixed waveguide face. Propagation direction is from right side $b$ ) to left side a)
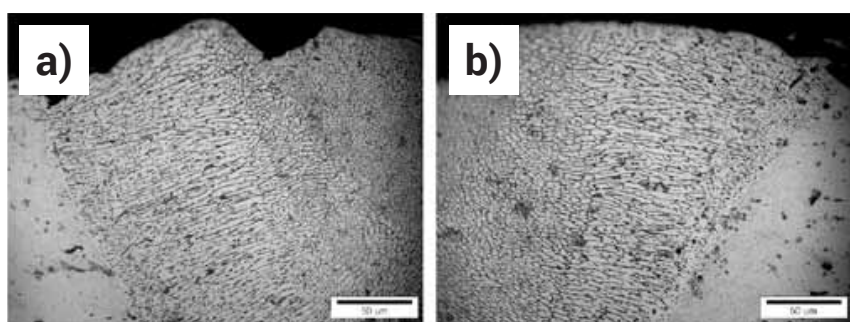

Rys. 6. Struktura wtopienia układanego metodą LW na stopie aluminium 2017A z zastosowaniem drgań ultradźwiękowych. Kierunek propagacji drgań od strony prawej napoiny b) do strony lewej a). Przekrój poprzeczny wykonany w odległości $z=0,127$ m od mocowanego czoła falowodu

Fig. 6. Structure of 2017 A alloy after laser welding with ultrasonic vibration. Cross section at the distance $\mathrm{z}=0,127 \mathrm{~m}$ from the fixed waveguide face. Propagation direction is from right side $b$ ) to left side a) 

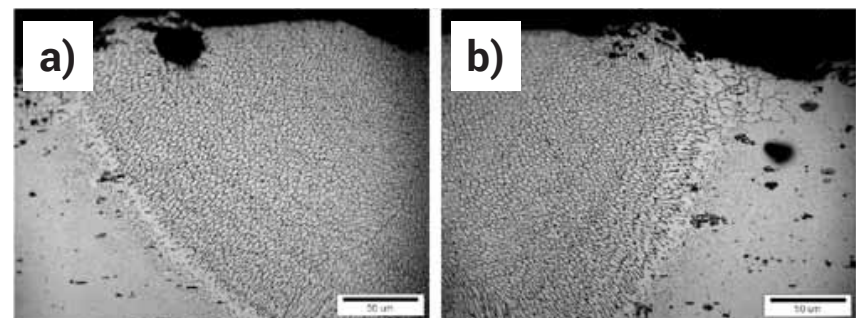

Rys. 7. Struktura wtopienia układanego metodą LW na stopie aluminium 2017A z zastosowaniem drgań ultradźwiękowych. Kierunek propagacji drgań od strony prawej napoiny b) do strony lewej a). Przekrój poprzeczny wykonany w odległości $z=0,159 \mathrm{~m}$ od mocowanego czoła falowodu

Fig. 7. Structure of $2017 \mathrm{~A}$ alloy after laser welding with ultrasonic vibration. Cross section at the distance $z=0,159 \mathrm{~m}$ from the fixed waveguide face. Propagation direction is from right side b) to left side a)
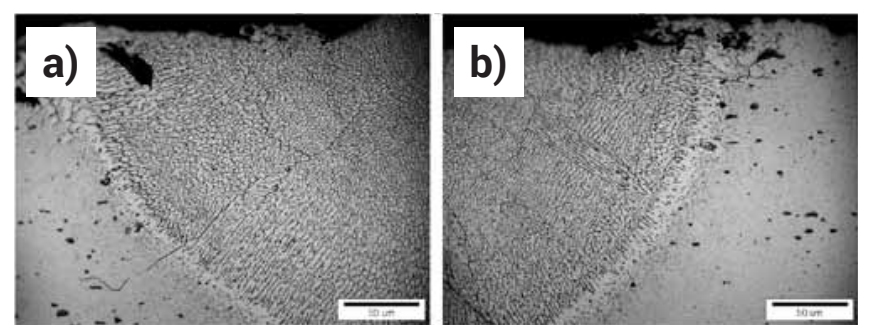

Rys. 8. Struktura wtopienia układanego metodą LW na stopie aluminium 2017A z zastosowaniem drgań ultradźwiękowych. Kierunek propagacji drgań od strony prawej napoiny b) do strony lewej a). Przekrój poprzeczny wykonany $w$ odległości $z=0,1905 \mathrm{~m}$ od mocowanego czoła falowodu

Fig. 8. tructure of 2017A alloy after laser welding with ultrasonic vibration. Cross section at the distance $z=0,1905 \mathrm{~m}$ from the fixed waveguide face. Propagation direction is from right side b) to left side a)

\section{Analiza kąta wzrostu ziaren i pochylenia linii wtopienia}

Wprowadzanie ultradźwiękowych drgań podłużnych o dużym natężeniu podczas wtapiania laserem falowodu ze stopu aluminium 2017A spowodowało zmiany w nachyleniu linii wtopienia i kierunków wzrostu ziaren. Na rysunku 9 zilustrowano te zaobserwowane przypadki, w zależności od współrzędnej z przybliżając rzeczywisty zarys linii wtopienia cięciwami. Przyjęto następujące oznaczenia: LW1 - linia wtopienia od strony wejścia fali drgań z fazy stałej do ciekłej, LW2 - linia wtopienia od strony wyjścia fali drgań z fazy ciekłej do stałej, LWG1 - linia wyznaczająca kierunek wzrostu ziarna podczas krzepnięcia w obszarze lica wtopienia od strony wejścia fali drgań, LWG2 - linia wyznaczająca kierunek wzrostu ziarna podczas krzepnięcia w obszarze lica wtopienia od strony wyjścia fali drgań, LWD1 - linia wyznaczająca kierunek wzrostu ziarna podczas krzepnięcia w obszarze grani wtopienia od strony wejścia fali drgań, LWD2 - linia wyznaczająca kierunek wzrostu ziarna podczas krzepnięcia w obszarze grani wtopienia od strony wyjścia fali drgań.

Na rysunku 10 pokazano zależność zmiany kąta linii wtopienia i kierunku wzrostu ziaren dla wtopień uzyskanych za pomocą lasera, w zależności od wartości współrzędnej z.

Można zauważyć, że występuje pewna zależność kąta nachylenia linii wtopienia od tego, czy drgania wnikają do ciekłego jeziorka, czy też z niego wychodzą.

Wartości kątów mierzono od linii prostopadłej do kierunku rozchodzenia się drgań. Można zauważyć, że kąt pochylenia linii wtopienia zależy, zarówno od współrzędnej z, jak i od rodzaju granicy faz: ciekła/stała (2/1) oraz stała/ciekła (1/2).
Wyraźnie widać, iż w przypadku współrzędnej z $\neq 0,127$ m kąt pochylenia linii wtopienia od strony wprowadzania drgań jest mniejszy, niż w okolicy „strzałki” drgań. Ponadto można zauważyć, iż wartości kątów pochylenia linii wtopienia uzyskane przy wprowadzaniu drgań, w porównaniu do wartości otrzymanych bez ich zastosowania, są większe (z wyłączeniem przypadku linii wtopienia, kiedy to drgania wychodzą z fazy ciekłej do stałej).

Okazuje się także, że i kierunek wzrostu ziaren zależy od współrzędnej z i rodzaju granicy ośrodków. I tak, w przypadku lica wtopienia, zarówno przy wprowadzaniu drgań z fazy stałej do ciekłej, jaki i wychodzeniu drgań z ciekłej fazy do stałej, obserwuje się podobne tendencje w pochyleniu linii wzrostu ziaren. W obu przypadkach, kiedy drgania wchodzą do jeziorka ciekłego metalu, jaki i przy ich wyjściu notuje się wyraźny wzrost wartości kąta nachylenia linii wzrostu ziaren (od 20 do $\left.35^{\circ}\right)$.

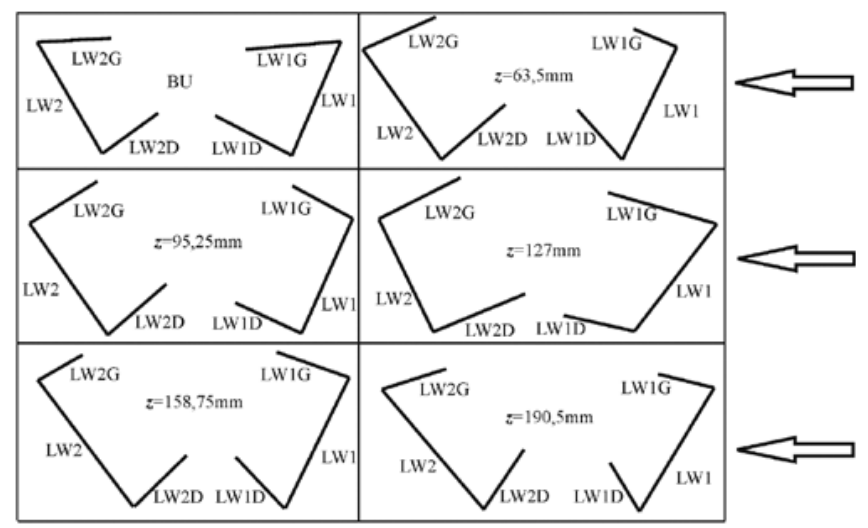

Rys. 9. Wtopienia uzyskane wiązką lasera przy udziale drgań ultradźwiękowych. Poszczególne przypadki ułożeń linii wtopienia LW1-2 i kierunków wzrostu ziaren LW1D, LW2D, LW1G i LW2G dla różnych wartości współrzędnej z; strzałkami zaznaczono kierunek wprowadzania drgań

Fig. 9. Schemes representing the fusion lines (LW1-2) and grain growth lines (LW1D, LW2D, LW1G and LW2G) for laser welds according to variable coordinate $z$. Arrows show the vibration propagation direction
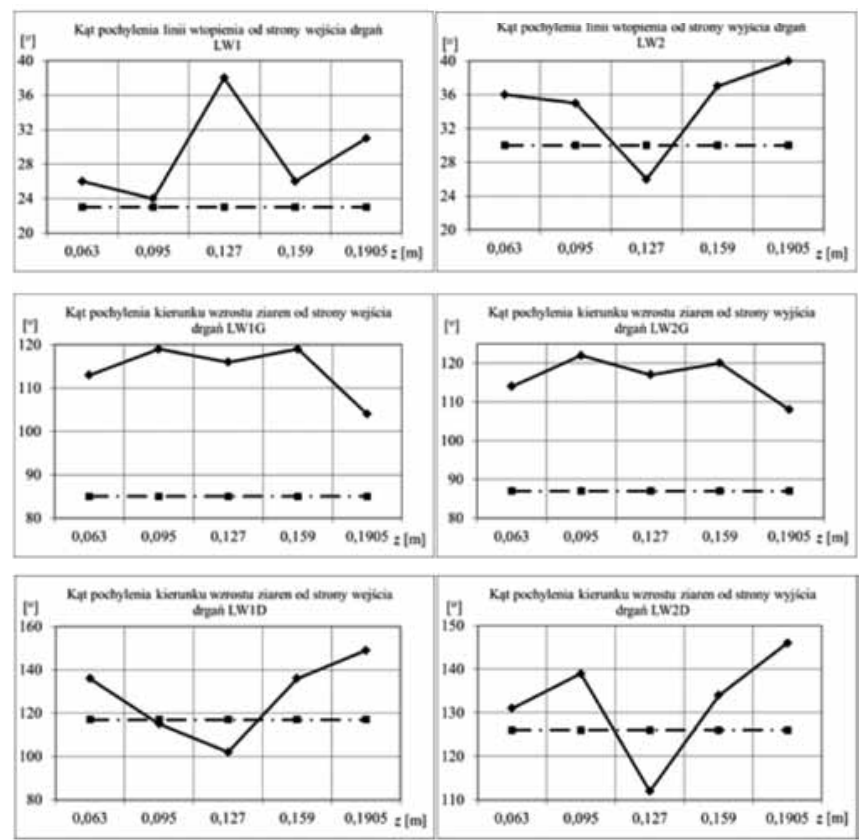

Rys. 10. Zmiany kąta linii wtopienia i kierunku wzrostu ziaren przetopień uzyskanych za pomocą lasera w zależności od współrzędnej z, (linia przerywana reprezentuje odpowiednie średnie wartości kątów nachylenia linii wtopienia, bez udziału drgań)

Fig. 10. Laser welded Fusion lines and grain growth lines relationships from the coordinate $z$ (interrupted line represent suitable average angle values of fusion line and grain growth line) 
Określenie kierunku wzrostu ziaren dla przypadków z rysun-

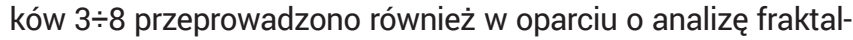
ną. Do analizy wybrano obrazy o wymiarach 256x256 pikseli, pochodzące $z$ obszaru w pobliżu linii wtopienia. (rys. 11). Następnie poddano je obróbce w programie ImageJ, w efekcie której otrzymano reprezentację binarną z widocznymi granicami ziaren oraz wydzieleniami. Następnie, wykorzystując program opracowany w Zakładzie Inżynierii Spajania Politechniki Warszawskiej, określono wartości wymiaru fraktalnego stosując metodę LCD (Line Counting Dimension). Metoda LCD jest modyfikacją metody BCD (Box Counting Dimension), w której siatkę pomiarową zastąpiono linią pomiarową [8]. Skanowanie linią pomiarową prowadzono wzdłuż linii prostopadłej do osi przetopienia. Otrzymane wartości zamieszczono w tablicy I i II. Kierunek krystalizacji (wzrostu ziaren) określono wykorzystując $w$ tym celu obraz amplitudowy FFT (Fast Fourier Transformation) badanej struktury (rys. 12). Kierunek określono za pomocą kąta między nim a osią pionową przetopienia (rys. 13). Otrzymane wartości podano w tablicy III.

Analizując otrzymane wartości wymiaru fraktalnego określonego za pomocą metody LCD (tablica I i II) stwierdzono niższe jego wartości dla struktur otrzymanych przy zastosowaniu drgań. Porównując wartości wymiaru fraktalnego liniowego dla odpowiednich struktur z lewej i prawej strony niższe wartości średnie odnotowano dla struktur z lewej strony. Histogramy wartości wymiaru fraktalnego, otrzymane dla poszczególnych struktur przetopień, miały charakter unimodalny. Mniejszymi wartościami rozstępu charakteryzowały się struktury z lewej strony przetopień (poza przypadkiem z=0,1905 m). Współczynnik zmienności dla struktur z lewej strony nie przekracza (poza przypadkiem z=0,1905 m) wartości 5\%, natomiast dla struktur $z$ prawej strony (poza przypadkiem struktury odniesienia oraz $\mathrm{z}=0,0635 \mathrm{~m}$ ) przyjmuje wartości z zakresu 5 $6 \%$.

Kąt wyznaczający kierunek krystalizacji (tabl. III, rys. 14) przyjmuje na ogół większe wartości dla struktur przetopień wykonanych przy współudziale drgań niż dla struktur odniesienia, przy czym dla struktur ze strony lewej zmiany są mniejsze niż dla struktur ze strony prawej.
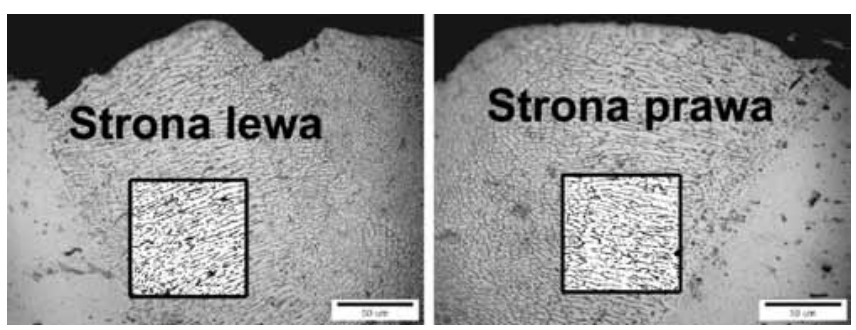

Rys. 11. Reprezentacyjne obszary pozyskania obrazów do analizy Fig. 11. The black rectangle defines a region-of-interest

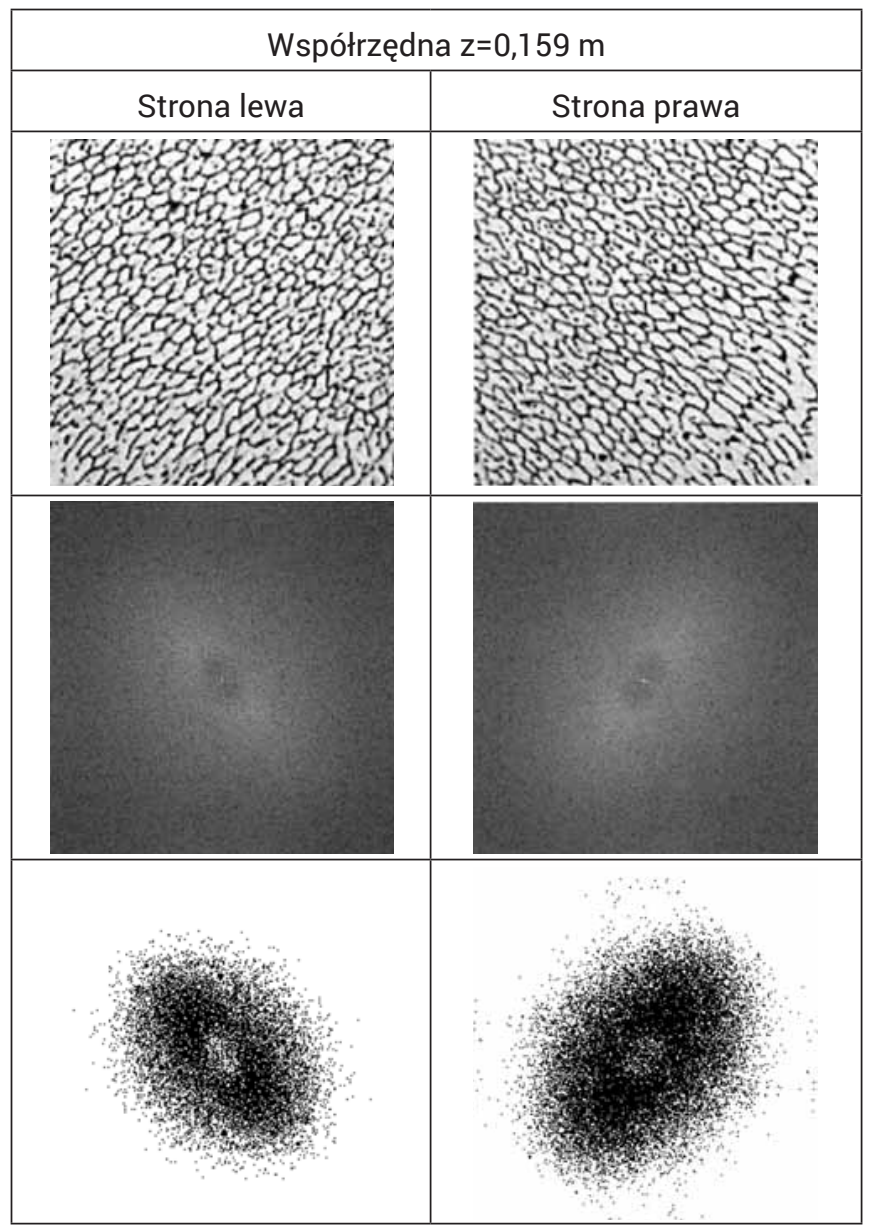

Rys. 12. Przykładowe a) obrazy struktur, b) obrazy FFT c) obrazy FFT po operacji progowania

Fig. 12. a) Images of structures, b) FFT images c) FFT images after thresholding operation

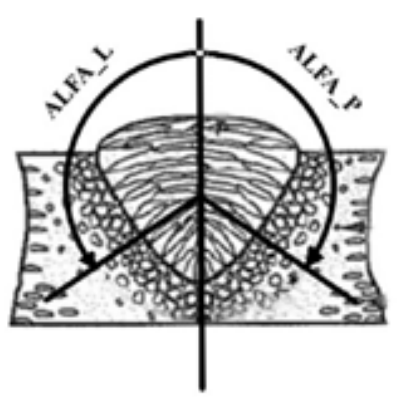

Rys. 13. Określenie kierunku krystalizacji

Fig. 13. Crystallization direction

Tablica I. Wymiar fraktalny badanych struktur przetopień

Table I. Fraktal dimension of analyzed structures

\begin{tabular}{|c|c|c|c|c|c|c|c|}
\hline \multirow{2}{*}{$\begin{array}{c}\text { Współrzędna } \\
\text { z [m] }\end{array}$} & \multicolumn{7}{|c|}{ Wymiar fraktalny dla struktur ze strony lewej (wyjście drgań) } \\
\hline & $F_{L\llcorner\text { min }}$ & FD LLmean & $\mathrm{FD}_{\text {LLmax }}$ & $\mathrm{R}$ & Var & S & CV [\%] \\
\hline Bez drgań & $\left.0,6465^{\star}\right)$ & $\left.0,7463^{\star}\right)$ & $\left.0,8212^{\star}\right)$ & 0,1747 & 0,0009 & 0,0301 & 4,03 \\
\hline 0,0635 & 0,6576 & 0,7393 & 0,8116 & 0,1540 & 0,0009 & 0,0305 & 4,13 \\
\hline 0,095 & 0,6131 & 0,7071 & 0,8152 & 0,2021 & 0,0012 & 0,0351 & 4,97 \\
\hline 0,127 & 0,5809 & 0,6673 & 0,7490 & 0,1681 & 0,0010 & 0,0331 & 4,96 \\
\hline 0,159 & 0,6320 & 0,7326 & 0,7967 & 0,1647 & 0,0009 & 0,0306 & 4,17 \\
\hline 0,1905 & 0,4800 & 0,6722 & 0,7900 & 0,3100 & 0,0018 & 0,0428 & 6,36 \\
\hline \multicolumn{8}{|c|}{$\begin{array}{l}\text { FDLLmin, mean, max - wartość minimalna, średnia, maksymalna dla struktur ze strony lewej } \\
\text { FD LP min, mean, max - wartość minimalna, średnia, maksymalna dla struktur ze strony prawej } \\
\text { R - rozstęp, Var - wariancja, S - odchylenie standardowe, CV - współczynnik zmienności } \\
\text { *) - wartości dla struktur odniesienia, uzyskanych bez stosowania fali ultradźwiękowej }\end{array}$} \\
\hline
\end{tabular}


Tablica II. Wymiar fraktalny badanych struktur przetopień

Table II. Fraktal dimension of analyzed structures

\begin{tabular}{|c|c|c|c|c|c|c|c|}
\hline \multirow{2}{*}{$\begin{array}{l}\text { Współrzędna } \\
\text { z [m] }\end{array}$} & \multicolumn{7}{|c|}{ Wymiar fraktalny dla struktur ze strony prawej (wejście drgań) } \\
\hline & FD LLmin & FD LLmean & FD $D_{\text {LLmax }}$ & $\mathrm{R}$ & Var & S & CV [\%] \\
\hline Bez drgań & $0,6479 *)$ & $\left.0,7552^{*}\right)$ & $\left.0,8286^{*}\right)$ & 0,1807 & 0,0012 & 0,0359 & 4,76 \\
\hline 0,0635 & 0,6328 & 0,7487 & 0,8117 & 0,1789 & 0,0009 & 0,0307 & 4,10 \\
\hline 0,095 & 0,5982 & 0,7129 & 0,7997 & 0,2015 & 0,0018 & 0,0426 & 5,98 \\
\hline 0,127 & 0,6039 & 0,7228 & 0,8210 & 0,2171 & 0,0018 & 0,0428 & 5,93 \\
\hline 0,159 & 0,5962 & 0,7401 & 0,8118 & 0,2156 & 0,0015 & 0,0390 & 5,28 \\
\hline 0,1905 & 0,5761 & 0,7091 & 0,8174 & 0,2413 & 0,0015 & 0,0397 & 5,60 \\
\hline \multicolumn{8}{|c|}{$\begin{array}{l}\text { FD } D_{L L m i n} \text { mean, max - wartość minimalna, średnia, maksymalna dla struktur ze strony lewej } \\
\text { FD LP min, mean, max - wartość minimalna, średnia, maksymalna dla struktur ze strony prawej } \\
\text { R - rozstęp, Var - wariancja, S - odchylenie standardowe, CV - współczynnik zmienności } \\
\text { *) - wartości dla struktur odniesienia, uzyskanych bez stosowania fali ultradźwiękowej }\end{array}$} \\
\hline
\end{tabular}

Tablica III. Kierunki krystalizacji badanych struktur przetopień

Table III. Crystallization directions of analyzed structures

\begin{tabular}{|c|c|c|}
\hline Współrzędna z [m] & ALFA [stopnie] & ALFAp [stopnie] \\
\hline Bez drgań & $\left.123^{\star}\right)$ & $\left.106^{\star}\right)$ \\
\hline 0,0635 & 131 & 100 \\
\hline 0,095 & 130 & 104 \\
\hline 0,127 & 111 & 133 \\
\hline 0,159 & 136 & 170 \\
\hline 0,1905 & 157 & \\
\hline \multirow{2}{*}{$*$}
\end{tabular}
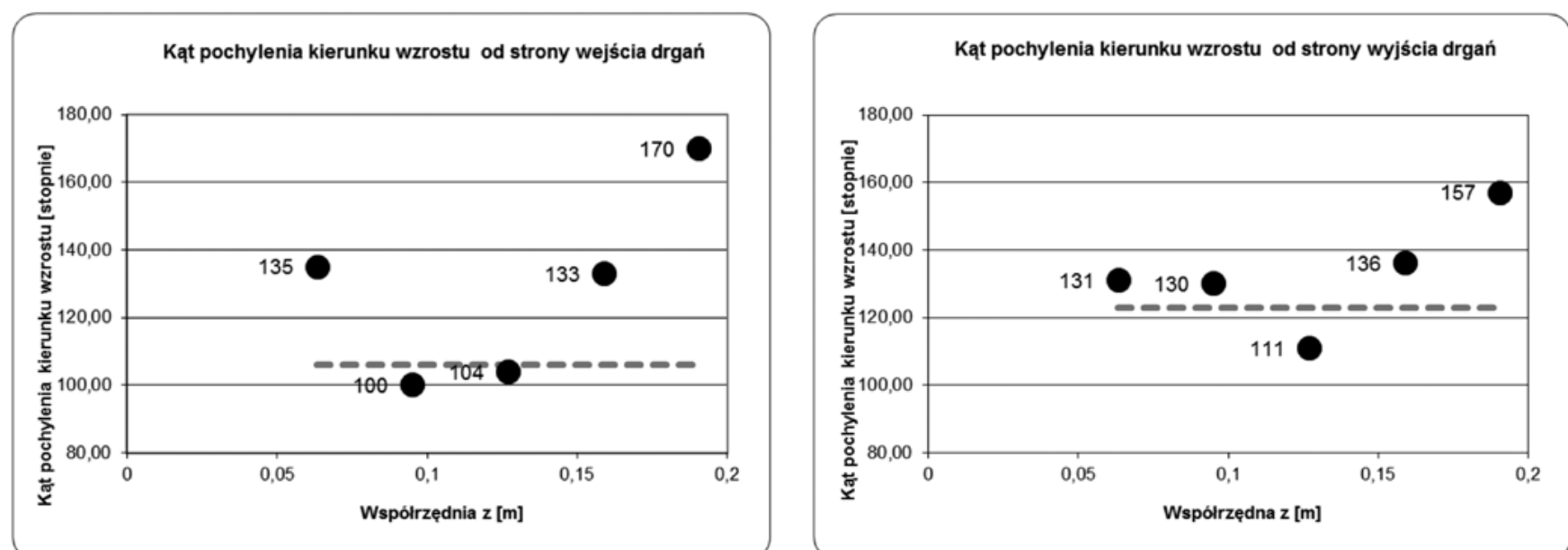

Rys. 14. Kierunek wzrostu kryształów w funkcji położenia przetopienia (linie przerywane - wartości dla struktur odniesienia)

Fig. 14. Crystallization direction as function of coordinates $z$ (dot lines - reference structure)

\section{Podsumowanie}

Zastosowanie drgań ultradźwiękowych wprowadzanych poprzecznie do przetopień nie pozostało bez wpływu na ich strukturę wyraźnie wyróżniając obszary od strony wejścia i wyjścia drgań choć różnice te nie dyskwalifikują charakterystyki przetopień. Można zatem wprowadzić do złącza lub przetopienia drgania poprzecznie w stosunku do kierunku posuwu źródła ciepła, uzyskać zamierzony efekt charakteryzujący budowę ziarnistą i nie doprowadzić jednocześnie do nieakceptowalnych zmian geometrii przetopienia. O zmianach kierunku krystalizacji związanej z wprowadzaniem drgań świadczą także niższe wartości wymiaru fraktalnego dla struktur przetopień wykonanych z zastosowaniem drgań, w porównaniu ze strukturami odniesienia, wykonanymi bez ich udziału. Otrzymane wyniki sugerują 
również, iż położenie przetopienia, rozumiane jako odległość od miejsca wprowadzenia drgań (współrzędna z), wywiera wpływ na jego strukturę (przede wszystkim kierunek krystalizacji i pochylenie linii wtopienia). Wyniki analizy fraktalnej wykazały dobrą zgodność z wynikami pomiarów przeprowadzonych wcześniej na zdjęciach struktur przetopień, potwierdzając tym samym celowość stosowania analizy fraktalnej do oceny zmian występujących w badanych strukturach.

\section{Literatura}

[1] Krajewski A., Wpływ drgań mechanicznych wykorzystywanych w procesach spajania na właściwości połączeń, zeszyt 258, ISSN 978-837814-118-1, Oficyna Wydawnicza Politechniki Warszawskiej, 2013

[2] Krajewski A., Hudycz M., Grześ J., Wpływ drgań ultradźwiękowych na kształt i strukturę napoin ze stopu aluminium wykonanych metodą MIG, Przegląd Spawalnictwa, nr 6, str. 3-11, 2014.

[3] Balasubramanian K., Studies on the effect of vibration on hot cracking and grain size in AA7075 aluminum alloy welding, International Journal of Engineering Science and Technology, Vol. 3, nr 1, s.681-685, 2011

[4] Takehiko Watanabe, Masataka Shiroki, Atsushi Yanagisawa, Tomohiro Sasaki, Improvement of mechanical properties of ferritic stainless steel weld metal by ultrasonic vibration, Journal of Materials Processing Technology, Niigata, Japan 27 May 2010.

[5] Lei Yu-cheng, Wang Zhi-wei, Chen Xi-zhang, Effect of arc-ultrasound on microstructures and mechanical properties of plasma arc welded joints of SiCp/Al MMCs, Science Direct, Zhenjiang, Harbin, China 6 July 2010.
[6] Honggang Donga, LiqunYanga, Chuang Dongb, SindoKouca, Improving arc joining of $\mathrm{Al}$ to steel and Al to stainless steel, Journal of Materials Processing Technology, Dalian, China/ Madison, USA, 24 November 2011.

[7] Krajewski A., Włosiński W., Chmielewski T., Kołodziejczak P., Ultrasonic-vibration assisted arc-welding of aluminum alloys, Bulletin of the Polish Academy of Science, ISSN 0239-7528, Vol. 60, No. 4, pp. 841-852, 2012.

[8] Grześ J., Wymiar fraktalny wybranych struktur złącza spawanego ze stali H17, Prace Naukowe - Mechanika, z. 229: 23-31, Oficyna Wydawnicza Politechniki Warszawskiej 2009. 